\title{
Total Synthesis of Tetranormethyl-calcimycin
}

\author{
Yoshiaki Nakahara, Akira Fujita and Tomoya Ogawa \\ RIKEN (The Institute of Physical and Chemical Research), \\ Wako-shi, Saitama 351-01, Japan \\ Received August 29, 1986
}

\begin{abstract}
The title compound $\mathbf{2}$ was synthesized. Asymmetric epoxidation of $\mathbf{9}$ followed by reductive cleavage of the epoxide $\mathbf{1 0}$ and acidification gave a symmetrical spiroketal (3), to which pyrrole and benzoxazole moieties were introduced in an efficient manner by the previously developed method. Since the synthetic material was less stable than natural calcimycin under basic conditions, cleavage of the methyl ester was achieved with LiI-pyridine.
\end{abstract}

A divalent cation ionophore, calcimycin (A23187) 1, was isolated from a culture of Streptomyces chartreusensis. ${ }^{1)}$ The unique structure $^{2)}$ of this antibiotic as well as its significant role in biochemical studies has drawn much attention from synthetic chemists. Evans', 3) Grieco's ${ }^{4)}$ and our groups ${ }^{5)}$ have accomplished the total synthesis of $\mathbf{1}$ in the independently developed manner of stereocontrol. Several reports have also appeared describing the preparations of calcimycin analogs which might be helpful, not only to elucidate the ionophoric action in biological systems, but also to develop new chemotherapeutic agents. Among them, chemical modifications of natural calcimycin have been achieved principally at the pyrrole and/or benzoxazole ring in the molecule through either halogenation ${ }^{6 a)}$ or semisynthesis. ${ }^{6 b, c)} \mathrm{We}$ would like to clarify the role played by methyl groups attached to the carbon framework of $\mathbf{1}$, which might either contribute to the structural stability of the dioxaspiro ring system or enhance the permeability across biological membranes. From this viewpoint, we started our project on synthetic studies of unnatural calcimycin analogs, and now describe a total synthesis of the tetranormethyl analog 2 , lacking four methyl groups at C-11, 15, 17 and 19.

We have already shown a successful strategy for the synthesis of this type of complex molecule, in which construction of the chiral di- oxaspiro ring system was accomplished prior to the attachment of pyrrole and benzoxazole rings. The symmetrical structure of the dioxaspirane framework in the target compound 2 indicated the advantage of an approach to this molecule through the intermediacy of the spiroketal intermediate 3. Pyrrole and benzoxazole moieties would be successively introduced to the spiro compound 3 through the appropriate chemical conversion of each side chain in the molecule. A plausible precursor of the spiroketal 3 was $(3 S, 11 S)$-7-oxotridecan1,3,11,13-tetraol (4) that was expected to give the desired "anomeric" configuration(s) at the spiro center by thermodynamically controlled ring closure. ${ }^{7)}$ The chiral ketotetraol would be prepared by using the asymmetric epoxidation and reduction procedure developed by Sharpless et $a .^{8,9)}$ In this manner, our synthesis was realized as shown in scheme 3 .

Methyl acetoacetate (5) was alkylated twice with 4-bromo-1-butene in separate steps to give 6, which was converted to the ketal 7 in a

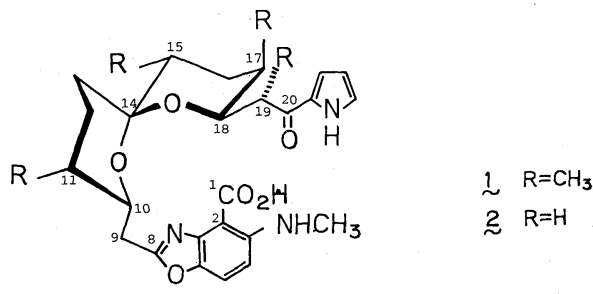

SCHEME 1.
1 $\mathrm{R}=\mathrm{CH}_{3}$ ¿ $\mathrm{R}=\mathrm{H}$ 


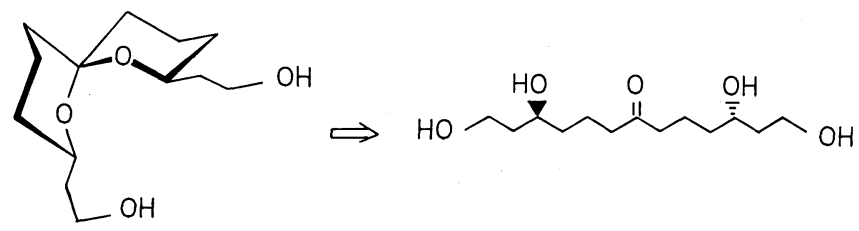

3

SCHEME 2.
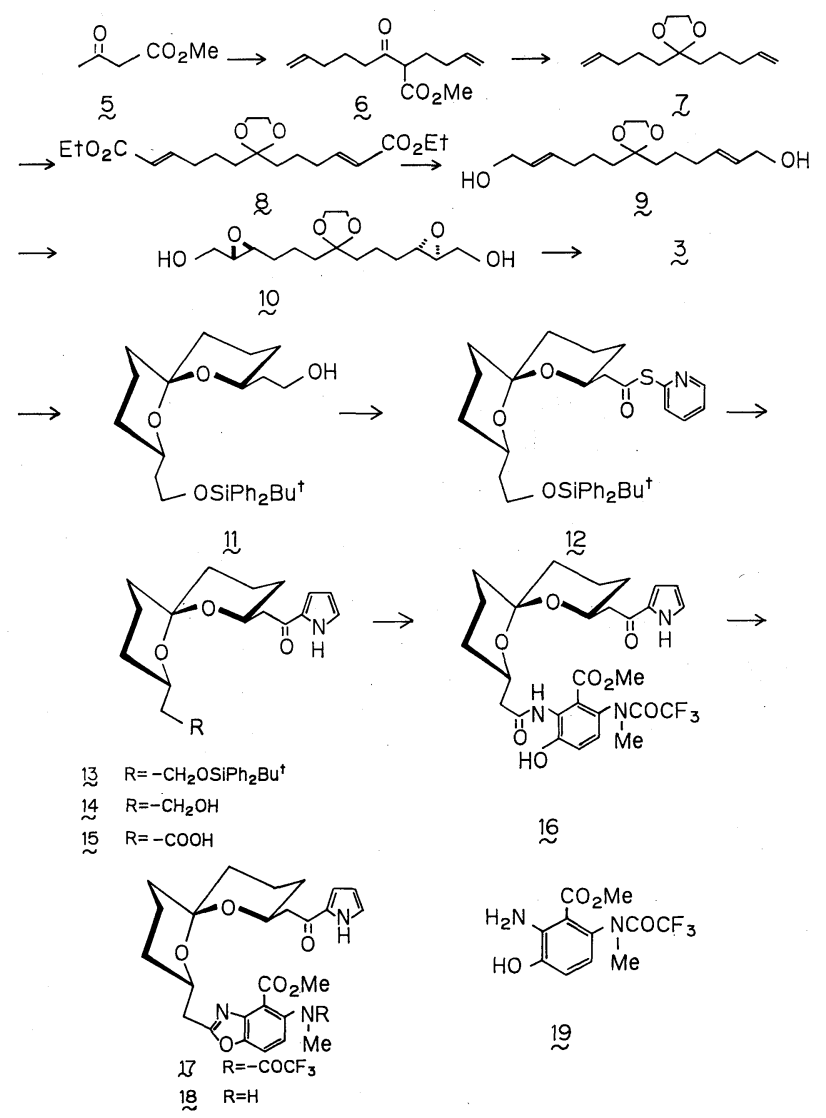

SCHEME 3.

moderate yield via saponification, decarboxylation and ketalization. Ozonolysis of 7 followed by a reductive workup gave a dialdehyde which, upon a Wittig reaction with the stable phosphorane $\left(\mathrm{Ph}_{3} \mathrm{P}=\mathrm{CHCOOEt}\right)$, afforded the diester 8 in a $73 \%$ overall yield. The desired $E, E$-isomer was readily separated from the minor $(<6 \%) E, Z$-isomer by column chromatography on silica gel. Reduction of $\mathbf{8}$ with DIBAL gave the corresponding diol 9, which was used as the substrate for asymmetric epoxidation.

According to the reported procedure, ${ }^{8)}$ the dienediol 9 was treated with titanium tetraisopropoxide and $t$-butyl hydroperoxide using (+)-diethyl tartrate. The reaction took place slowly at $-20^{\circ} \mathrm{C}$, and the diepoxide 10 was obtained in a $50 \sim 58 \%$ yield after 3 days. It 
was then submitted to regioselective epoxide opening by reducing with Red-al. Without isolating the resultant tetraol, the reaction mixture was heated with a large excess of $10 \%$ phosphoric acid, resulting in hydrolysis of the ketal and concomitant cyclization to the spiroketal 3. The isolated product $(67.5 \%)$ was a single isomer indicated by seven signals for its ${ }^{13} \mathrm{C}-\mathrm{NMR}$ spectrum, and had a specific rotation of $+97.7^{\circ} .^{10)}$

In order to make the introduction of a pyrrole ring selective to the symmetrical molecule, one of the hydroxyl groups had to be masked during the process. Selective monoprotection was not effected even with a bulky silylating agent $\left(t-\mathrm{BuPh}_{2} \mathrm{SiCl} /\right.$ imidazole $)$ and the yield of the desired mono-silyl ether 11 was moderate $(40 \sim 46 \%)$. The accompanying bissilyl ether $(25 \sim 30 \%)$, however, could be quantitatively returned to the starting diol 3 by treating with tetra- $n$-butylammonium fluoride. The mono-protected compound $\mathbf{1 1}$ was oxidized with $8 \mathrm{~N}$ Jones' reagent to the corresponding carboxylic acid, which, without purification, was converted to the 2-pyridylthiolester $^{11)} 12$ in a $67 \%$ yield. According to the previously developed procedure by our group ${ }^{12)}$ regioselective acylation of the pyrrole with 12 was effected in an $86 \%$ yield with pyrrolylmagnesium bromide in the presence of cuprous iodide.

The next task, construction of the characteristic benzoxazole system, was done as follows. Removal of the silyl protecting group with the fluoride ion gave 14, which was oxidized with $8 \mathrm{~N}$ Jones' reagent at $-20^{\circ} \mathrm{C}$ to the carboxylic acid $\mathbf{1 5}$ in a $77 \%$ overall yield. Condensation of $\mathbf{1 5}$ with an aminophenol $(19)^{5)}$ was achieved with the help of benzotriazol-1-yloxytris(dimethylamino)phosphonium hexafluorophosphate (BOP) $)^{13)}$ to give an amide (16), which was heated with a catalytic amount of pyridinium $p$-toluenesulfonate $^{14)}$ in dichloroethane to produce the benzoxazole drivative $\mathbf{1 7}$ in a reasonable yield. Completion of the synthesis required deprotecting the amino and carboxyl groups. The conventional method for deprotection under basic conditions, including those reported for calcimycin and its analogs (e.g., $\mathrm{KOH} / \mathrm{EtOH}$, $\mathrm{K}_{2} \mathrm{CO}_{3}$ /aq. $\mathrm{MeOH}$ and $\operatorname{LiSPr}^{\mathrm{n}} / \mathrm{DMF}$ ), however, resulted in extensive decomposition. Although none of the decomposed products was characterized, it can be presumed that this molecule was more alkaline-labile than the natural material due to the absence of four methyl groups in the framework. Careful screening of the conditions gave us a reasonable solution to this problem. The trifluoroacetyl group was removed under a mildly basic condition ( $\mathrm{LiOH}, \mathrm{H}_{2} \mathrm{O}_{2}$, THF, $0^{\circ} \mathrm{C}, 3 \mathrm{hr}$ ) and then the methyl ester was cleaved with lithium iodide in boiling pyridine. After acidification with dil. $\mathrm{HCl}$, the product was extracted at $\mathrm{pH}$ $3 \sim 4$ and purified on a column packed with citric acid-impregnated silica gel. ${ }^{6 b)}$ In this manner, the desired tetranormethyl calcimycin 2 was obtained in a $77 \%$ yield. The physical data (NMR, MS and $\left.[\alpha]_{\mathrm{D}}\right)$ of the sample confirmed the assigned structure 2 , and its chromatographic behavior was found to be very similar to the natural material $\mathbf{1}$.

Having synthesized the target analog $\mathbf{2}$ in an unambiguous way, this compound $\mathbf{2}$ was submitted to biological evaluation. Compound 2, however, exhibited no activity comparable with natural calcimycin $\mathbf{1}$ in our study of the contractile response in smooth muscle from guinea pig ileum. ${ }^{15)}$ Since we observed a high affinity of this normethyl compound 2 toward the calcium ion in the course of the experiments, its loss of biological activity may be explained in terms of the decreased lipophilicity of this synthetic analog, which would have prevented the facile transport of the calcium ion through the cell membrane. In conclusion, our synthetic studies could demonstrate the crucial role played by the methyl groups of calcimycin in order to exhibit its biological activity.

\section{EXPERIMENTAL}

All boiling points (bp) and melting points (mp) are uncorrected. ${ }^{1} \mathrm{H}-\mathrm{NMR}$ and ${ }^{13} \mathrm{C}-\mathrm{NMR}$ spectra were measured with JEOL JNMFX90Q and GX 400 spectrometers. IR spectra were recorded on a Shimadzu IR-430 
spectrophotometer, and mass spectra were obtained with a Hitachi M-80 mass spectrometer. Optical rotations were measured with a Perkin-Elmer 141 polarimeter.

5-Carbomethoxy-6-oxo-1,10-undecadiene (6). A dianion solution of methyl acetoacetate $(12.5 \mathrm{ml}, 116.3 \mathrm{mmol})$ was prepared with a $60 \% \mathrm{NaH}(5.0 \mathrm{~g}, 125.1 \mathrm{mmol})$ and $1.36 \mathrm{~N}$ $n$-BuLi hexane solution, $(92.0 \mathrm{ml}, 125.1 \mathrm{mmol})$ in dry THF $(200 \mathrm{ml})$, according to the literature. ${ }^{16)}$ To the solution was added 4-bromo-1-butene $(15.0 \mathrm{ml}, 147.8 \mathrm{mmol})$ with stirring at $0^{\circ} \mathrm{C}$ under Ar, stirring being continued for $2 \mathrm{hr}$. $\mathrm{AcOH}$ was then added to the mixture to destroy any excess base, and the mixture was concentrated in vacuo. The residue was diluted with water and extracted with ether. The extract was washed with water and brine, and then dried $\left(\mathrm{MgSO}_{4}\right)$. Removal of the solvent gave a crude material $(18.2 \mathrm{~g})$, which was used for the next reaction without purification. A mixture of this product and 4bromo-1-butene $(21.7 \mathrm{ml}, 214 \mathrm{mmol})$ in $\mathrm{CHCl}_{3}(80 \mathrm{ml})$ was added to a mixture of $n-\mathrm{Bu}_{4} \mathrm{NHSO}_{3}(36.4 \mathrm{~g}, 107 \mathrm{mmol})$ and $\mathrm{NaOH}(8.56 \mathrm{~g}, 214 \mathrm{mmol})$ in water $(80 \mathrm{ml})$ with stirring in an ice-cooled water bath. The mixture was then stirred at room temperature for $6 \mathrm{hr}$, before the $\mathrm{CHCl}_{3}$ layer was separated and concentrated in vacuo. The residue was diluted with ether, washed with water and brine, and dried $\left(\mathrm{MgSO}_{4}\right)$. After removing the solvent, the residue was distilled under reduced pressure to give $6(10.7 \mathrm{~g}$, $41.2 \%$ ). bp $117 \sim 122^{\circ} \mathrm{C} / 3 \mathrm{mmHg}$. IR $v_{\max }$ (neat) 3100 , $1745,1720,1640 \mathrm{~cm}^{-1} .{ }^{1} \mathrm{H}-\mathrm{NMR}\left(\mathrm{CDCl}_{3}\right) \delta 1.5 \sim 2.7$ $(11 \mathrm{H}, \mathrm{m}), 3.72(3 \mathrm{H}, \mathrm{s}), 4.8 \sim 5.2(4 \mathrm{H}, \mathrm{m}), 5.5 \sim 6.0(2 \mathrm{H}, \mathrm{m})$. Anal. Found: C, 69.45; $\mathrm{H}, 8.96$. Calcd. for $\mathrm{C}_{13} \mathrm{H}_{20} \mathrm{O}_{3}$ : C, $69.61 ; \mathrm{H}, 8.99 \%$.

6-Ethylenedioxy-1,10-undecadiene (7). A mixture of 6 $(40 \mathrm{~g}, 178 \mathrm{mmol}), \mathrm{Ba}(\mathrm{OH})_{2}(119 \mathrm{~g}), 95 \% \mathrm{EtOH}(140 \mathrm{ml})$ and water $(374 \mathrm{ml})$ was heated under reflux for $19 \mathrm{hr}$. After cooling, the mixture was poured into a dilute $\mathrm{HCl}$ solution $(12 \mathrm{~N} \mathrm{HCl}, 60 \mathrm{ml}$; water, $800 \mathrm{ml})$, stirred for $1 \mathrm{hr}$ at room temperature, and then extracted with ether. The extract was successively washed with water, satd. $\mathrm{NaHCO}_{3}$ and brine, and then dried $\left(\mathrm{MgSO}_{4}\right)$. Removal of the solvent gave an oil $(26.7 \mathrm{~g})$, which was heated with ethyleneglycol $(19.9 \mathrm{~g}, 320 \mathrm{mmol})$ and $p$-TsOH $(0.2 \mathrm{~g})$ in benzene $(300 \mathrm{ml})$ under reflux in a Dean-Stark water separator for $3 \mathrm{hr}$. The mixture was washed well with aqueous $\mathrm{NaHCO}_{3}$ and brine. After removing the solvent, the residue was distilled under reduced pressure to give $7(23.5 \mathrm{~g}, 62.5 \%)$. bp $80 \sim 82^{\circ} \mathrm{C} / 2 \mathrm{mmHg}$. IR $v_{\max }$ (neat) $3100,1640 \mathrm{~cm}^{-1} \cdot{ }^{1} \mathrm{H}-$ NMR $\left(\mathrm{CDCl}_{3}\right) \delta 1.20 \sim 1.75(8 \mathrm{H}, \mathrm{m}), 1.90 \sim 2.20(4 \mathrm{H}, \mathrm{m})$, $3.92(4 \mathrm{H}, \mathrm{s}), 4.82 \sim 5.12(4 \mathrm{H}, \mathrm{m}), 5.55 \sim 6.02(2 \mathrm{H}, \mathrm{m}) .{ }^{13} \mathrm{C}-$ NMR 23.1, 33.9, 36.6, 64.9, 111.7, 114.5, 138.6.

Diethyl 7-ethylenedioxy-2,11-tridecenedioate (8). Ozonized oxygen was bubbled through a cold solution of 7 $(11.0 \mathrm{~g}, 52.3 \mathrm{mmol})$ in $\mathrm{CH}_{2} \mathrm{Cl}_{2}(800 \mathrm{ml})$ in a dry ice-cooled acetone bath until the blue color of ozone resulted. The excess oxidant was then removed by bubbling of $\mathrm{N}_{2}$.
Aqueous $\mathrm{AcOH}(\mathrm{AcOH}, 66 \mathrm{ml}$; water, $6.6 \mathrm{ml}$ ) was added to the mixture, and $\mathrm{Zn}$-dust (55 $\mathrm{g}$ ) was then added portionwise to the vigorously stirred mixture. After completing the addition, the bath was removed and stirring was continued for $1.5 \mathrm{hr}$ at room temperature. The insoluble material was filtered off, before the filtrate was carefully washed with a mixture of satd. $\mathrm{NaHCO}_{3}$ and satd. $\mathrm{NaCl}$ $(1: 1)$, and finally dried $\left(\mathrm{Na}_{2} \mathrm{SO}_{4}\right)$. After removing the solvent, the crude dialdehyde $(11.3 \mathrm{~g})$ obtained was stirred with ethyl triphenylphosphoranylideneacetate $(28.3 \mathrm{~g}$, $114 \mathrm{mmol})$ in dry benzene $(200 \mathrm{ml})$ at room temperature. The mixture was concentrated in vacuo to remove benzene and the residue was extracted with $n$-hexane. The insoluble material was removed by filtration, and a $n$-hexane solution was concentrated in vacuo. The crude product was chromatographed on silica gel $(1 \mathrm{~kg})$ in $n$-hexane-EtOAc (7:3) to afford $\mathbf{8}(13.5 \mathrm{~g}, 73.1 \%)$ and its $E, Z$-isomer $(1.0 \mathrm{~g})$ as the less polar fraction. IR $v_{\max }$ (neat), $1715,1650 \mathrm{~cm}^{-1}$. ${ }^{1} \mathrm{H}-\mathrm{NMR}\left(\mathrm{CDCl}_{3}\right) \delta 1.28(6 \mathrm{H}, \mathrm{t}, J=7.3 \mathrm{~Hz}), 1.44 \sim 1.70$ $(8 \mathrm{H}, \mathrm{m}), 2.08 \sim 2.35(4 \mathrm{H}, \mathrm{m}), 3.92(4 \mathrm{H}, \mathrm{s}), 4.18(4 \mathrm{H}, \mathrm{q}, J=$ $7.3 \mathrm{~Hz}), 5.82(2 \mathrm{H}, \mathrm{dm}, J=15.6 \mathrm{~Hz}), 6.95(2 \mathrm{H}, \mathrm{dt}, J=15.6$, $6.8 \mathrm{~Hz}) .{ }^{13} \mathrm{C}-\mathrm{NMR}\left(\mathrm{CDCl}_{3}\right)$ 14.3, 22.3, 32.2, 36.7, 60.1, 65.0, 111.2, 121.6, 148.6, 166.6. E,Z-isomer: ${ }^{1} \mathrm{H}-\mathrm{NMR}$ $\left(\mathrm{CDCl}_{3}\right) \delta 1.28(6 \mathrm{H}, \mathrm{t}, J=7.3 \mathrm{~Hz}), 1.40 \sim 1.70(8 \mathrm{H}, \mathrm{m})$, $2.08 \sim 2.80(4 \mathrm{H}, \mathrm{m}), 3.92(4 \mathrm{H}, \mathrm{s}), 4.16(2 \mathrm{H}, \mathrm{q}, J=7.0 \mathrm{~Hz})$, $4.18(2 \mathrm{H}, \mathrm{q}, J=7.3 \mathrm{~Hz}), 5.76(1 \mathrm{H}, \mathrm{dm}, J=11.7 \mathrm{~Hz}), 5.81$ $(1 \mathrm{H}, \mathrm{dm}, J=15.8 \mathrm{~Hz}), 6.20(1 \mathrm{H}, \mathrm{dt}, J=6.5 \mathrm{~Hz}), 6.95(1 \mathrm{H}$, $\mathrm{dt}, J=15.8,6.8 \mathrm{~Hz}$ ).

7-Ethylenedioxy-2,11-tridecene-1,13-diol (9). To a solution of $8(4.9 \mathrm{~g}, 13.8 \mathrm{mmol})$ in dry $\mathrm{CH}_{2} \mathrm{Cl}_{2}(100 \mathrm{ml})$ was added a $1.76 \mathrm{~N}$ diisobutylaluminum hydride $n$-hexane solution (DIBAL, $31.3 \mathrm{ml}, 55.1 \mathrm{mmol}$ ) with stirring under $\mathrm{Ar}$ in an ice-cooled water bath. After stirring for $1 \mathrm{hr}$ at $0^{\circ} \mathrm{C}$, the mixture was diluted with ether $(300 \mathrm{ml})$. The excess reducing agent was then destroyed by carefully adding water, and to the mixture was then added a satd. potassium sodium tartrate solution $(100 \mathrm{ml})$. The mixture was stirred at room temperature for $20 \mathrm{~min}$, before the insoluble material was removed by filtration through celite. The organic layer separated was washed with satd. $\mathrm{NaHCO}_{3}$ and brine, dried $\left(\mathrm{Na}_{2} \mathrm{SO}_{4}\right)$, and evaporated in vacuo. The crude product was purified by column chromatography on silica gel $(450 \mathrm{~g})$ in $\mathrm{CHCl}_{3}-\mathrm{MeOH}(95: 5)$ to give $9(3.3 \mathrm{~g}, 88.6 \%)$ as an oil. ${ }^{1} \mathrm{H}-\mathrm{NMR}\left(\mathrm{CDCl}_{3}\right) \delta 1.20 \sim$ $172(8 \mathrm{H}, \mathrm{m}), 1.9 \sim 2.1(4 \mathrm{H}, \mathrm{m}), 2.20(2 \mathrm{H}$, br. s), 3.92 $(4 \mathrm{H}, \mathrm{s}), 4.02 \sim 4.10(4 \mathrm{H}, \mathrm{m}), 5.5 \sim 5.7(4 \mathrm{H}, \mathrm{m}) .{ }^{13} \mathrm{C}-\mathrm{NMR}$ $\left(\mathrm{CDCl}_{3}\right)$ 23.4, 32.2, 36.7, 63.5, 64.9, 111.7, 129.5, 132.6.

[2R,3S,11S,12R]-2,3-,11,12-Diepoxy-7-ethylenedioxytridecane-1,13-diol (10). According to the literature, ${ }^{8)}$ titanium tetraisopropoxide $(1.29 \mathrm{ml}, 4.44 \mathrm{mmol})$ and $\mathrm{L}$ (+)-diethyl tartrate $(0.78 \mathrm{ml}, 4.44 \mathrm{mmol})$ were dissolved in dry $\mathrm{CH}_{2} \mathrm{Cl}_{2}(200 \mathrm{ml})$ under $\mathrm{N}_{2}$ with stirring in a dry icecooled $\mathrm{CCl}_{4}$ bath. The mixture was stirred for $30 \mathrm{~min}$. The substrate $9(2.0 \mathrm{~g}, 7.4 \mathrm{mmol})$ and then a $3.9 \mathrm{M} t$-butylhydroperoxide $/ \mathrm{CH}_{2} \mathrm{Cl}_{2}$ solution $(19 \mathrm{ml}, 74 \mathrm{mmol})$ were 
added to the mixture. The resulting mixture was stored for 4 days in a freezer at about $-20^{\circ} \mathrm{C}$. The mixture was diluted with ether $(200 \mathrm{ml})$, stirred for $15 \mathrm{~min}$ with diethyleneglycol $(0.94 \mathrm{~g}, 8.88 \mathrm{mmol})$ and a satd. $\mathrm{Na}_{2} \mathrm{SO}_{4}$ solution $(1.0 \mathrm{ml})$, and then filtered through celite. The filtrate was concentrated in vacuo and the residue was co-evaporated with toluene to remove the water. The crude product was purified by flash-chromatography on silica gel $(500 \mathrm{~g})$ with EtOAc-acetone $(4: 1)$ containing pyridine $(1 \%)$ to give $\mathbf{1 0}$ $(1.31 \mathrm{~g}, 58.4 \%) .[\alpha]_{\mathrm{D}}^{27}-33.8^{\circ}\left(c=0.49, \mathrm{CHCl}_{3}\right) \cdot{ }^{1} \mathrm{H}-\mathrm{NMR}$ $\left(\mathrm{CDCl}_{3}\right) \delta 1.4 \sim 1.7(12 \mathrm{H}, \mathrm{m}), 2.7(2 \mathrm{H}$, br. s), $2.8 \sim 3.0(4 \mathrm{H}$, m), $3.6 \sim 3.9(4 \mathrm{H}, \mathrm{m}), 3.92(4 \mathrm{H}, \mathrm{s})$. Anal. Found: C, 59.84; $\mathrm{H}, 8.79$. Calcd. for $\mathrm{C}_{15} \mathrm{H}_{26} \mathrm{O}_{6}: \mathrm{C}, 59.58 ; \mathrm{H}, 8.67 \%$.

[2S,6S,8S]-2,8-Bis-(2-hydroxyethyl)-1,7-dioxaspiro[5,5]undecane (3). To a solution of $\mathbf{1 0}(385 \mathrm{mg}, 1.27 \mathrm{mmol})$ in dry THF $(5 \mathrm{ml})$ was added a solution of sodium bis(2methoxyethoxy)aluminum hydride $(3.4 \mathrm{M}$ Red-al/toluene, $1.2 \mathrm{ml}, 4.1 \mathrm{mmol})$ in dry THF $(10 \mathrm{ml})$ in a dry ice-cooled acetone bath. The mixture was stirred for $2.5 \mathrm{hr}$ at $-78^{\circ}$ and then gradually warmed to ambient temperature after removing the bath. Stirring was continued for $2.5 \mathrm{hr}$. To the mixture was carefully added $10 \%$ phosphoric acid $(40 \mathrm{ml})$, before the mixture was heated under reflux for $5 \mathrm{hr}$. After cooling, the resultant mixture was concentrated in vacuo to remove most of the THF and then extracted with EtOAc-ether $(1: 1)$. The extract was washed with water and brine, and dried $\left(\mathrm{Na}_{2} \mathrm{SO}_{4}\right)$. Removal of the solvent in vacuo gave a solid, which was recrystallized from $n$-hexane-EtOAc to give $3(178 \mathrm{mg})$. The mother liquor was concentrated and chromatographed on silica gel (10 g) with EtOAc-acetone $(9: 1)$ to afford an additional amount $(32 \mathrm{mg}$ ) of 3 (total yield, 67.5\%). mp 118 $119^{\circ} \mathrm{C} .[\alpha]_{\mathrm{D}}^{27}+97.7^{\circ}\left(c=0.44, \mathrm{CHCl}_{3}\right) \cdot{ }^{1} \mathrm{H}-\mathrm{NMR}\left(\mathrm{CDCl}_{3}\right)$ $\delta 1.1 \sim 1.9(16 \mathrm{H}, \mathrm{m}), 3.2(2 \mathrm{H}$, br. s), $3.6 \sim 4.1(6 \mathrm{H}, \mathrm{m})$. ${ }^{13} \mathrm{C}-\mathrm{NMR}\left(\mathrm{CDCl}_{3}\right)$ 19.1, 31.2, 35.3, 38.5, 60.3, 67.8, 96.4. Anal. Found: C, 64.04; H, 9.91. Calcd. for $\mathrm{C}_{13} \mathrm{H}_{24} \mathrm{O}_{4}$ : C, $63.91 ; \mathrm{H}, 9.91 \%$.

$[2 S, 6 S, 8 S]-2-(2-t-B u t y l d i p h e n y l$ silyloxyethyl $)-8-(2-$ hydroxyethyl)-1,7-dioxaspiro[5,5] undecane (11). A mixture of $3(890 \mathrm{mg}, 3.64 \mathrm{mmol})$, imidazole $(496 \mathrm{mg}, 7.29 \mathrm{mmol})$ and $t-\mathrm{BuPh}_{2} \mathrm{SiCl}(1 \mathrm{ml}, 3.83 \mathrm{mmol})$ in dry DMF $(20 \mathrm{ml})$ was stirred for $2 \mathrm{hr}$ in an ice-cooled water bath. The mixture was diluted with ether $(300 \mathrm{ml})$ and successively washed with water and brine. The ethereal extract was dried $\left(\mathrm{Na}_{2} \mathrm{SO}_{4}\right)$ and concentrated in vacuo. The resultant product was chromatographed on silica gel $(100 \mathrm{~g})$ with $n$ hexane-EtOAc $(7: 3)$ to give a bis-silylated compound $(871 \mathrm{mg}, 33.2 \%)$ and $11(720 \mathrm{mg}, 40.9 \%)$. Finally, the column was eluted with EtOAc-acetone $(9: 1)$ to afford unreacted $3(178 \mathrm{mg}, 20.1 \%) .[\alpha]_{\mathrm{D}}^{27}+33.9^{\circ} \quad(c=1.4$, $\left.\mathrm{CHCl}_{3}\right) .{ }^{1} \mathrm{H}-\mathrm{NMR}\left(\mathrm{CDCl}_{3}\right) \delta 1.05(9 \mathrm{H}, \mathrm{s}), 1.90 \sim 1.75$ $(16 \mathrm{H}, \mathrm{m}), 2.95$ (1H, br. s), $3.73 \sim 3.84(6 \mathrm{H}, \mathrm{m}), 7.33 \sim 7.44$ $(6 \mathrm{H}, \mathrm{m}), 7.61 \sim 7.73(4 \mathrm{H}, \mathrm{m})$. Anal. Found: C, 72.46; H, 8.87. Cacld. for $\mathrm{C}_{29} \mathrm{H}_{42} \mathrm{O}_{4} \mathrm{Si}: \mathrm{C}, 72.16 ; \mathrm{H}, 8.77 \%$. The bissilylated compound was treated with $n-\mathrm{Bu}_{4} \mathrm{NF}$ in THF at room temperature to quantitatively regenerate the starting diol 3.

[2S,6S,8S]-2-(2-t-Butyldiphenylsilyloxyethyl)-8-[2-oxo2-(pyrid-2-ylthio)ethyl]-1,7-dioxaspiro[5,5]undecane (12). A solution of $11(276 \mathrm{mg}, 0.57 \mathrm{mmol})$ in acetone $(70 \mathrm{ml})$ was cooled in an ice-cooled $\mathrm{MeOH}$ bath. Jones' reagent $(8 \mathrm{~N}$, $0.7 \mathrm{ml}$ ) was added dropwise to the solution with stirring. After stirring for $20 \mathrm{~min}$, the excess oxidant was destroyed by adding $\mathrm{MeOH}$. The mixture was stirred for a further $5 \mathrm{~min}$ and then diluted with water $(40 \mathrm{ml})$. After adjusting to $\mathrm{pH} 4.0$ by adding a satd. $\mathrm{NaHCO}_{3}$ solution, the mixture was concentrated to remove most of the acetone. The resulting aqueous layer was extracted with EtOAc-ether $(1: 1)$. The extract was washed with water and brine, and then dried $\left(\mathrm{MgSO}_{4}\right)$. Removal of the solvent gave a crude carboxylic acid $(274 \mathrm{mg})$, which was treated with $2,2^{\prime}$ dipyridyldisulfide $(201 \mathrm{mg}, 0.91 \mathrm{mmol})$ and triphenylphosphine $(239 \mathrm{mg}, 0.91 \mathrm{mmol})$ in dry $\mathrm{CH}_{2} \mathrm{Cl}_{2}(20 \mathrm{ml})$ at room temperature for $3 \mathrm{hr}$. The mixture was concentrated in vacuo and the residue was chromatographed on silica gel $(125 \mathrm{~g})$ with $n$-hexane-EtOAc $(7: 3)$ to afford $12(226 \mathrm{mg}$, $66.9 \%) \cdot[\alpha]_{\mathrm{D}}^{27}+23.8^{\circ}\left(c=0.6, \mathrm{CHCl}_{3}\right) . \mathrm{IR}$ (neat) $v_{\max } 1730$, $1700 \mathrm{~cm}^{-1} .{ }^{1} \mathrm{H}-\mathrm{NMR}\left(\mathrm{CDCl}_{3}\right) \delta 1.03(9 \mathrm{H}, \mathrm{s}), 1.17 \sim 2.03$ $(14 \mathrm{H}, \mathrm{m}), 2.70 \sim 2.79(2 \mathrm{H}, \mathrm{m}), 3.76 \sim 4.15(4 \mathrm{H}, \mathrm{m})$, $7.22 \sim 7.38(7 \mathrm{H}, \mathrm{m}), 7.55 \sim 7.72(6 \mathrm{H}, \mathrm{m}), 8.50 \sim 8.62(1 \mathrm{H}$, $\mathrm{m})$.

$[2 S, 6 S, 8 S]-2-(2-t-B u t y l d i p h e n y l s i l y l o x y e t h y l)-8-[2-o x o-$ 2-(1H-pyrrol-2-yl)ethyl]-1,7-dioxaspiro[5,5]undecane (13). A solution of pyrrolylmagnesium bromide $(0.5 \mathrm{~N}, 2.98 \mathrm{ml}$, $1.49 \mathrm{mmol})$ in ether-THF $(1: 1)$ was added to a suspension of $\mathrm{CuI}(141 \mathrm{mg}, 0.74 \mathrm{mmol})$ in dry THF $(0.9 \mathrm{ml})$ with stirring in an ice-cooled water bath, under Ar. After stirring for $30 \mathrm{~min}$, a solution of $12(293 \mathrm{mg}, 0.49 \mathrm{mmol})$ in dry THF $(4 \mathrm{ml})$ was added to the mixture, stirring being continued for $1.5 \mathrm{hr}$ at $0^{\circ} \mathrm{C}$. The mixture was then diluted with ether $(30 \mathrm{ml})$ and stirred with a satd. $\mathrm{NH}_{4} \mathrm{Cl}$ aqueous solution $(9 \mathrm{ml})$ for $15 \mathrm{~min}$. The insoluble material was filtered off through celite, before the filtrate was washed with water and brine, dried $\left(\mathrm{MgSO}_{4}\right)$ and finally evaporated. Chromatography of the residue on silica gel $(35 \mathrm{~g})$ in $n$-hexane-EtOAc $(9: 1)$ afforded $13(233 \mathrm{mg}, 85.9 \%)$. $[\alpha]_{\mathrm{D}}^{21}+15.5^{\circ}\left(c=0.8, \mathrm{CHCl}_{3}\right)$. IR (neat) $v_{\max } 1730 \mathrm{~cm}^{-1}$. ${ }^{1} \mathrm{H}-\mathrm{NMR}\left(\mathrm{CDCl}_{3}\right) \delta 1.03(9 \mathrm{H}, \mathrm{s}), 1.11 \sim 1.80(14 \mathrm{H}, \mathrm{m})$, $2.74(1 \mathrm{H}, \mathrm{dd}, J=5.5,14.3 \mathrm{~Hz}), 2.89(1 \mathrm{H}, \mathrm{dd}, J=7.6$, $14.3 \mathrm{~Hz}), 3.55(1 \mathrm{H}, \mathrm{m}), 3.68 \sim 3.81(2 \mathrm{H}, \mathrm{m}), 4.02(1 \mathrm{H}, \mathrm{m})$, $6.14(1 \mathrm{H}, \mathrm{m}), 6.84(1 \mathrm{H}, \mathrm{m}), 6.91(1 \mathrm{H}, \mathrm{m}), 7.35 \sim 7.43(6 \mathrm{H}$, m), $7.66 \sim 7.69$ (4H, m), 9.31 (1H, br. s). Anal. Found: C, 72.46; H, 7.95; N, 2.50. Calcd. for $\mathrm{C}_{33} \mathrm{H}_{43} \mathrm{NO}_{4} \mathrm{Si}: \mathrm{C}, 72.62$; $\mathrm{H}, 7.94 ; \mathrm{N}, 2.57 \%$.

[2S,6S,8S]-2-(2-hydroxyethyl)-8-[2-oxo-2-(1H-pyrrol2-yl)-ethyl]-1,7-dioxaspiro[5,5]undecane (14). To a solution of $13(212 \mathrm{mg}, 0.39 \mathrm{mmol})$ in THF $(3 \mathrm{ml})$ was added a $1 \mathrm{~N}$ $n$ - $\mathrm{Bu}_{4} \mathrm{NF}-\mathrm{THF}$ solution $(3 \mathrm{ml})$. After stirring for $50 \mathrm{~min}$ at room temperature, the mixture was diluted with ether 
$(80 \mathrm{ml})$, washed with water and brine, and dried $\left(\mathrm{Na}_{2} \mathrm{SO}_{4}\right)$. Removal of the solvent and subsequent chromatography on silica gel $(25 \mathrm{~g})$ with $n$-hexane-EtOAc $(7: 3)$ gave 14 $(110 \mathrm{mg}, 92 \%),[\alpha]_{\mathrm{D}}^{19}+71.4^{\circ}\left(c=0.73, \mathrm{CHCl}_{3}\right)$. IR (neat) $v_{\max } 3300,1730 \mathrm{~cm}^{-1} .{ }^{1} \mathrm{H}-\mathrm{NMR}\left(\mathrm{CDCl}_{3}\right) \delta 1.15 \sim 2.17$ $(15 \mathrm{H}, \mathrm{m}), 2.63(1 \mathrm{H}, \mathrm{dd}, J=3.4,15.3 \mathrm{~Hz}), 3.12(1 \mathrm{H}, \mathrm{dd}, J=$ $9.5,15.3 \mathrm{~Hz}), 3.73(1 \mathrm{H}, \mathrm{m}), 3.84(1 \mathrm{H}, \mathrm{m}), 3.96(1 \mathrm{H}, \mathrm{m})$, $4.29(1 \mathrm{H}, \mathrm{m}), 6.28(1 \mathrm{H}, \mathrm{m}), 6.98(1 \mathrm{H}, \mathrm{m}), 7.04(1 \mathrm{H}, \mathrm{m})$, 9.49 (1H, br. s). Anal. Found: C, 66.36; H, 8.20; N, 4.56. Calcd. for $\mathrm{C}_{17} \mathrm{H}_{25} \mathrm{NO}_{4}$ : C, 66.43; H, 8.20; N, $4.56 \%$.

[2S,6S,8S]-2-Carboxymethyl-8-[2-oxo-2-(1H-pyrrol-2$y$ l)ethyl]-1,7-dioxaspiro[5,5]undecane (15). Jones' reagent $(8 \mathrm{~N}, 4.4 \mathrm{ml})$ was added dropwise to a stirred solution of 14 $(740 \mathrm{mg}, 2.4 \mathrm{mmol})$ in acetone $(200 \mathrm{ml})$ in an ice-cooled $\mathrm{MeOH}$ bath. After stirring for $20 \mathrm{~min}$, the excess oxidant was destroyed by adding $\mathrm{MeOH}$. The mixture was then diluted with water, and satd. $\mathrm{NaHCO}_{3}$ solution was added to adjust the $\mathrm{pH}$ to 4.0. Most of acetone was removed by evaporation. The resulting aqueous layer was extracted with EtOAc-ether $(1: 1)$. The extract was washed with brine, dried $\left(\mathrm{MgSO}_{4}\right)$, and evaporated. Chromatography of the residue on silica gel $(70 \mathrm{~g})$ in EtOAc-iso-PrOH (95:5) containing AcOH (3\%) afforded 15 (645 mg, $83.4 \%$ ) as crystals. mp $130 \sim 131^{\circ} \mathrm{C}$ (recrystallized from $n$ hexane-iso-PrOH). $[\alpha]_{\mathrm{D}}^{27}+32.1^{\circ}\left(c=0.56, \mathrm{CHCl}_{3}\right)$. IR (KBr) $v_{\max } 3300,1730,1660 \mathrm{~cm}^{-1} \cdot{ }^{1} \mathrm{H}-\mathrm{NMR}\left(\mathrm{CDCl}_{3}\right)$ $\delta 1.10 \sim 1.90(12 \mathrm{H}, \mathrm{m}), 2.45(2 \mathrm{H}, \mathrm{m}), 2.79(1 \mathrm{H}, \mathrm{dd}, J=4.7$, $14.1 \mathrm{~Hz}), 3.03(1 \mathrm{H}, \mathrm{dd}, J=7.7,14.1 \mathrm{~Hz}), 3.99(1 \mathrm{H}, \mathrm{m}), 4.32$ $(1 \mathrm{H}, \mathrm{m}), 6.26(1 \mathrm{H}, \mathrm{m}), 7.02$ (1H, br.s), 7.11 (1H, br. s). Anal. Found: C, 63.61; H, 7.31; N, 4.36. Calcd. for $\mathrm{C}_{17} \mathrm{H}_{23} \mathrm{NO}_{5}$ : C, 63.54; $\mathrm{H}, 7.21 ; \mathrm{N}, 4.36 \%$.

$[2 S, 6 S, 8 S]-2-[6-H y d r o x y-5-(N-m e t h y l t r i f l u o r o a c e t-$ amido)-2-methoxycarbonylphenyl]carbamoylmethyl-8-[2oxo-2-(1H-pyrrol-2-yl)ethyl]-1,7-dioxaspiro[5,5]undecane (16). A mixture of 15 (117 mg, $0.364 \mathrm{mmol})$ and 19 (107 $\mathrm{mg}, 0.366 \mathrm{mmol})$ was coevaporated with dry toluene (10 $\mathrm{ml}$ ) to remove the moisture and then dissolved in dry DMF (2 ml). Benzotriazol-1-yloxytris(dimethylamino)phosphonium hexafluorophosphate (BOP, $170 \mathrm{mg}, 0.384$ mmol) and triethylamine $(102 \mu \mathrm{l})$ were added to this mixture, before heating with stirring at $60^{\circ} \mathrm{C}$ for $6 \mathrm{hr}$ in an atmosphere of argon. After cooling, the mixture was diluted with EtOAc-ether $(1: 1)$, washed with water and brine, dried $\left(\mathrm{Na}_{2} \mathrm{SO}_{4}\right)$, and evaporated. Chromatography of the residue on silica gel in toluene-EtOAc $(7: 3)$ afforded $16(182 \mathrm{mg}, 83.9 \%)$. $[\alpha]_{\mathrm{D}}^{22}-12.0^{\circ}\left(c=3.9, \mathrm{CHCl}_{3}\right)$. IR (neat) $v_{\max } 3300,1730,1695,1640 \mathrm{~cm}^{-1} .{ }^{1} \mathrm{H}-\mathrm{NMR}$ $\left(\mathrm{CDCl}_{3}\right) \delta 3.25$ (3H, br. s), $3.90(3 \mathrm{H}, \mathrm{s}), 4.0 \sim 4.4(2 \mathrm{H}, \mathrm{m})$, $6.25(1 \mathrm{H}, \mathrm{m}), 6.96(1 \mathrm{H}, \mathrm{m}), 7.0 \sim 7.2(3 \mathrm{H}, \mathrm{m}), 9.07(1 \mathrm{H}$, br.). Anal. Found: C, 56.16; H, 5.36; N, 6.92. Calcd. for $\mathrm{C}_{28} \mathrm{H}_{32} \mathrm{~N}_{3} \mathrm{O}_{8} \mathrm{~F}_{3}$ : C, 56.47; H, 5.42; N, 7.06\%.

$[2 S, 6 S, 8 S]-8-[2-O x o-2-(1 H-p y r r o l-2-y l) e t h y l]-2-[5-(N-$ methyltrifluoroacetamido)-4-methoxycarbonyl-benzoxazol2-yl]methyl-1,7-dioxaspiro[5,5]undecane (17). A mixture of
16 (164 $\mathrm{mg}, 0.275 \mathrm{mmol}$ ) and pyridinium $p$-toluenesulfonate (PPTS, $44 \mathrm{mg}, 0.175 \mathrm{mmol}$ ) in dichloroethane $(18 \mathrm{ml})$ was heated with stirring at $80 \sim 90^{\circ} \mathrm{C}$ for $9 \mathrm{hr}$. After cooling, the mixture was diluted with $\mathrm{CHCl}_{3}$, successively washed with satd. $\mathrm{NaHCO}_{3}$, water and brine, dried $\left(\mathrm{Na}_{2} \mathrm{SO}_{4}\right)$, and then evaporated. Chromatography of the residue on silica gel $(20 \mathrm{~g})$ in toluene-EtOAc $(65: 35 \sim 1: 1)$ afforded $17(64 \mathrm{mg})$ and unreacted $16(67 \mathrm{mg})$. The latter was again submitted to heating with PPTS and an additional amount ( $38 \mathrm{mg}$ ) of 17 was obtained (total, 64\%). $[\alpha]_{\mathrm{D}}^{24}+46.2^{\circ}\left(c=1.8, \mathrm{CHCl}_{3}\right) \cdot{ }^{1} \mathrm{H}-\mathrm{NMR}\left(\mathrm{CDCl}_{3}\right) \delta: 3.36$ $(3 \mathrm{H}, \mathrm{s}), 4.00(3 \mathrm{H}, \mathrm{s}), 4.34(1 \mathrm{H}, \mathrm{m}), 4.45(1 \mathrm{H}, \mathrm{m}), 6.30(1 \mathrm{H}$, $\mathrm{m}), 6.96(1 \mathrm{H}, \mathrm{m}), 7.05(1 \mathrm{H}, \mathrm{m}), 7.25(1 \mathrm{H}, \mathrm{d}, J=8.5 \mathrm{~Hz})$, $7.66(1 \mathrm{H}, \mathrm{d}, J=8.5 \mathrm{~Hz})$. MS. Found: 559.19276 . Calcd. for $\mathrm{C}_{28} \mathrm{H}_{28} \mathrm{~F}_{3} \mathrm{~N}_{3} \mathrm{O}_{6}\left(17-\mathrm{H}_{2} \mathrm{O}\right): 559.19298$.

Tetranormethyl-calcimycin (2). A solution of 17 (21 mg, $0.036 \mathrm{mmol})$ in THF $(4 \mathrm{ml})$ was cooled in an ice-cooled water bath. To the solution were added, with stirring, $\mathrm{H}_{2} \mathrm{O}_{2}(30 \%, 0.5 \mathrm{ml})$ and aqueous $\mathrm{LiOH}(1.25 \mathrm{~N}, 0.5 \mathrm{ml})$. After stirring for $3 \mathrm{hr}$ at $0^{\circ} \mathrm{C}$, the mixture was diluted with ether $(30 \mathrm{ml})$. The ethereal solution was successively washed with water, aqueous $\mathrm{Na}_{2} \mathrm{~S}_{2} \mathrm{O}_{3}$, water and brine, and then dried $\left(\mathrm{Na}_{2} \mathrm{SO}_{4}\right)$. Removal of the solvent gave a crude 18 (about $20 \mathrm{mg}$ ), which was heated under reflux with LiI ( $50 \mathrm{mg}, 0.374 \mathrm{mmol})$ in pyridine $(4.5 \mathrm{ml})$ for $2 \mathrm{hr}$ in an atmopshere of nitrogen. After cooling, the mixture was poured into ice-cooled water and acidified with diluted $\mathrm{HCl}(1 \mathrm{~N})$ to adjust the $\mathrm{pH}$ to $3 \sim 4$. The mixture was then extracted with ether. The ethereal extract was washed with water and brine, dried $\left(\mathrm{Na}_{2} \mathrm{SO}_{4}\right)$, and evaporated in vacuo. The residue was chromatographed on a column of citric acid-impregnated silica gel $^{6 \mathrm{~b})}(5 \mathrm{~g})$ in $n$-hexane-EtOAc $(1: 1)$. The fraction corresponding to 2 [ $R f 0.41$, on a silica gel HPTLC plate sprayed with citric acid, $n$-hexaneEtOAc (1:1)] was dissolved in ether. The ethereal solution was washed with water to remove the contaminating citric acid, and then dried $\left(\mathrm{Na}_{2} \mathrm{SO}_{4}\right)$. Removal of the solvent afforded $2(13 \mathrm{mg}, 76.5 \%)$. [ $\alpha]_{\mathrm{D}}^{23}+43.0^{\circ}\left(c=0.8, \mathrm{CHCl}_{3}\right)$. ${ }^{1} \mathrm{H}-\mathrm{NMR}\left(\mathrm{CDCl}_{3}\right) \delta 2.97(3 \mathrm{H}, \mathrm{d}, J=5.1 \mathrm{~Hz}), 4.37(1 \mathrm{H}, \mathrm{m})$, $6.26(1 \mathrm{H}, \mathrm{m}), 6.64(1 \mathrm{H}, \mathrm{d}, J=9.0 \mathrm{~Hz}), 6.90(1 \mathrm{H}, \mathrm{m}), 7.03$ $(1 \mathrm{H}, \mathrm{m}), 7.52(1 \mathrm{H}, \mathrm{d}, J=9.0 \mathrm{~Hz}), 8.10(1 \mathrm{H}, \mathrm{m}), 9.42(1 \mathrm{H}$, br.). MS. Found: 467.20449. Calcd. for $\mathrm{C}_{25} \mathrm{H}_{29} \mathrm{~N}_{3} \mathrm{O}_{6}$ : 467.20563.

Acknowledgments. We are indebted to Dr. M. Hachisu and Dr. S. Nakabayashi for carrying out the pharmacological test on 2. We thank Dr. J. Uzawa and Mrs. T. Chijimatsu for recoding and measuring the NMR spectra, Dr. H. Honma and his staff for the elemental analyses, and Mr. Y. Esumi for measuring high-resolution MS. We also thank Ms. A. Takahashi and Ms. K. Moriwaki for their technical assistance.

\section{REFERENCES AND NOTES}

1) R. L. Hamill, M. Gorman, R. M. Gale, C. E. 
Higgens and M. M. Hoehn, Abstracts of Papers, 12th Interscience Conference on Antimicrobial Agents and Chemotherapy, Atlantic City, N. J., Sept. $26 \sim 29,1972$, p. 65 .

2) M. O. Chaney, P. V. Demarco, N. D. Jones and J. L. Occolowitz, J. Am. Chem. Soc., 96, 1932 (1974).

3) D. A. Evans, C. E. Sacks, W. A. Kleschick and T. R. Taber, J. Am. Chem. Soc., 101, 6789 (1979).

4) a) P. A. Grieco, E. Williams, H. Tanaka and S. Gilman, J. Org. Chem., 45, 3537 (1980); b) G. R. Martinez, P. A. Grieco, E. Williams, K. Kanai and C. V. Srinivasan, J. Am. Chem. Soc., 104, 1436 (1982).

5) Y. Nakahara, A. Fujita and T. Ogawa, J. Carbohydr. Chem., 3, 487 (1984).

6) a) M. Debono, R. M. Molloy, D. E. Dorman, J. W. Paschal, D. F. Babcock, C. M. Deber and D. R. Pfeiffer, Biochemistry, 20, 6865 (1981); b) M. Prudhomme and G. Jeminet, Experientia, 39, 256 (1983); c) M. Prudhomme, G. Dauphin, J. Guyot and G. Jeminet, J. Antibiot., 37, 627 (1984).

7) Relative stability between the stereoisomers of 1,7-dioxaspiro[5,5]undecane was discussed: $\mathrm{P}$. Deslongchamps, D. D. Rowan, N. Pothier, T. Sauvé and J. K. Saunders, Can. J. Chem., 59, 1105 (1981).

8) T. Katsuki and K. B. Sharpless, J. Am. Chem. Soc., 102, 5974 (1980).

9) P. Ma, V. S. Martin, S. Masamune, K. B. Sharpless and S. M. Viti, J. Org. Chem., 47, 1378 (1982).

10). Racemic 3 has been reported: D. A. Evans, C. E. Sacks, R. A. Whitney, N. G. Mandel, Tetrahedron Lett., 1978, 727.

11) M. Araki, S. Sakata, H. Takei and T. Mukaiyama, Bull. Chem. Soc. Jpn., 47, 1777 (1974).

12) Y. Nakahara, A. Fujita and T. Ogawa, Agric. Biol. Chem., 49, 1491 (1985).

13) B. Castro, J. R. Dormoy, B. Dourtoglou, G. Evin, C. Selve and J. C. Ziegler, Synthesis, 1976, 751.

14) M. Miyashita, A. Yoshikoshi and P. A. Grieco, $J$. Org. Chem., 42, 3772 (1977).

15) K. Kubota "Yakurigaku Jisshu," II-6, Kodansha, 1977, p. 106.

16) S. N. Huckin and L. Weiler, J. Am. Chem. Soc., 96, 1082 (1974). 